\title{
Picturing power: the depiction of leadership in art
}

\author{
Nicholas O. Warner* \\ Professor of Literature, Interim Vice-President of Academic Affairs and Associate Dean of Faculty, \\ Claremont McKenna College, Claremont, CA, USA
}

This paper examines leadership as a theme in works of visual art. It begins by identifying some key theoretical issues that arise in the artistic depiction of leadership, especially in comparison to the depiction of leadership through the verbal medium of literature. The paper builds on some earlier studies of the depiction of leadership in art by describing the challenges, limitations, and advantages of studying that depiction from the dual perspectives of art history and of leadership studies, and links the above issues to the analysis of leadership in specific works of art.

Keywords: art, artistic media, charisma, leadership, literature, painting, verbal, visual

\section{INTRODUCTION: LEADERSHIP IN/AND ART}

In the waning years of his life, an exiled 72-year-old Frenchman who had been close to the seat of power before, during, and after the French Revolution wrote the following words to a younger colleague: 'Vite, vite, mon ami: feuilletez votre Plutarque' ('Quick, quick my friend: turn the pages of your Plutarch'). Anyone reading this statement might well assume its author to have been some once-great military or political figure, urging a youthful novice to lose no time in studying one of the most venerable volumes on leadership - Plutarch's Lives of the Noble Greeks and Romans. Plutarch's lofty reputation and subject matter would amply justify such an assumption. After all, Shakespeare drew on Plutarch to portray leaders in his Roman plays; Ralph Waldo Emerson declared the Lives to be a 'bible for heroes' (Emerson 1903, p. 318); and in our own time, the leadership scholar Barbara Kellerman (2010, p. 32) has described Plutarch's work as 'an ancient form of leadership education,' one that is 'timeless' in its relevance to the contemporary world.

But in truth, the injunction to study Plutarch was made not by a general, statesman, ruler, or business magnate. Rather, it came from the pen of the great French neoclassical painter, Jacques-Louis David. Though a recipient of royal commissions and lodgings in the Louvre, the successful court painter became an ardent Jacobin, even voting for the execution of Louis XVI. Narrowly escaping the guillotine himself, David went on to win favor with Napoleon, eventually becoming the emperor's chief painter. With the restoration of the Bourbon monarchy, the unrepentant Bonapartist ended his days as an exile in Belgium. Writing from Brussels to his brilliant former pupil, Antoine-Jean Gros, David urged the

\footnotetext{
* I wish to thank the journal's anonymous reviewers for their suggestions, and my colleagues Clayton Koppes of Oberlin College, and Ronald Riggio and Ellen Rentz of Claremont McKenna College, for reading and commenting on earlier drafts of this article.
} 
younger man not to delay in producing what always remained for David the ultimate artistic achievement - a grand historical painting with wide-ranging appeal. And the best source of subjects for such a painting? Plutarch's celebrated Lives. ${ }^{1}$

David's advice to Gros was intended to stimulate a fellow artist's painterly engagement with the heroic subject matter of antiquity. But the remark also points to a much broader issue - the depiction of leadership in art. Although conceding that the 'study and creation of works of art may seem ... rather far removed from leadership,' J. Thomas Wren (2009, p. 29) argues for the intimate connections between these areas; similarly, as the entry on 'Arts' in the Encyclopedia of Leadership points out (Küpers 2004, p. 47), it is only from a conventional and superficial perspective that 'art and aesthetics seem incompatible with corporate situations and relationships.' Indeed, the combination of leadership studies with art-historical analysis offers many opportunities for reciprocal illumination. Examining art through the lens of leadership can enhance our understanding both of individual artworks and of the profoundly human interactions that lie at the core of the leader-follower relationship, as some earlier studies of leadership in art have shown. ${ }^{2}$ Building on such studies, my own discussion here has the following aims: to identify some of the theoretical issues that arise in the artistic depiction of leadership; to describe the challenges, limitations, and advantages of studying that depiction from the dual perspectives of art history and of leadership studies; and to demonstrate the ways in which these issues emerge in several specific works of art.

The scholarly-critical approach I employ does not involve trawling works of art for nugget-like lessons on how or how not to lead. The study of leadership in art seeks not the gathering of a moral here and a pointer there, but a deeper understanding of leadership as a complex ethical, historical, and cultural phenomenon, with an equally complex relationship to the construction and manipulation of images. ${ }^{3}$ Neither does my discussion entail the acceptance of all artistic depictions of leadership at face value: with leadership, as with any other topic, some works may strike viewers as insightful, true, or even wise, while others may be rejected as propagandistic or false. As it happens, for the purposes of critical analysis, some of the most interesting works of art can actually be those that elicit responses quite different from, or even

1. David's letter has been often quoted; for comments on this letter and its relation to the art of Gros, see Delestre (1867, p. 15).

2. Two pioneering treatments of leadership in art appear in Joanne Ciulla's collected volume, Leadership and the Humanities (2008). In his contribution, Charles Johnson relates leadership to three art-historical topics: sculpture as an expression of civic and moral ideas in Renaissance Florence; the role of prints during the Reformation; and Daumier's use of caricature to critique the leadership of King Louis-Philippe in nineteenth-century France. In another chapter from the same volume, Scott Boylston examines networks of relation between art, graphic design, propaganda, business, politics, and social justice. Rather different in orientation, but still relevant to the exploration of leadership's relationship to art is Anu Mitru's (2011) essay, 'Learning to Look,' which approaches leadership more through the psychology of perception rather than the portrayal of subject matter. For an exemplary discussion of the ways that artists can provide cultural leadership, see Strauss (1984).

3. Much work remains to be done on the construction and perception of visual images of leaders, whether those images take the form of traditional works of art, media representations, and even events or spectacles that convey, in the broadest sense, an 'image' of the leader to the public. Among the theoretical classics in this area that deal mainly with the visual arts are Gombrich (1960); Bryson (1983, offering a vigorous challenge to Gombrich); Freedberg (1989); Sturken and Cartwright (2001); and Elkins (1996). A study focused on eighteenth-century Paris, but with broader relevance to the ways that politics can inform the creation and manipulation of artistic images, is Crow's Painters and Public Life in Eighteenth-Century Paris (1985). 
opposed to, those intended by the artist or assumed by a work's original audience. Thus, a work originally designed to elicit admiration for its subject may come to seem an exercise in public relations or damage control; a visual tribute to inspirational leadership can become an unintended parable of hubris or of the 'dark side' of charisma (Conger and Kanungo 1989, p. 5).

Epitomizing this phenomenon is the famous painting, Napoleon at the Pest House of Jaffa, completed by Antoine-Jean Gros in 1804. Here Napoleon reaches out to touch (implicitly to heal) with ungloved hand a victim of bubonic plague at Jaffa; the magnanimity of his gesture gains emphasis by its contrast to the behavior of his squeamish officers, standing timidly by. The painting clearly presents Napoleon as a courageous, compassionate, even semi-divine leader. And, like so many images of Napoleon, especially those he commissioned as his power and his egotism grew, this picture constitutes a visual version of the once-dominant 'great man' approach to leadership so familiar in the writings of Thomas Carlyle. Though tempering his admiration of Napoleon with criticism of a 'charlatan element' (Carlyle 1840, p. 285) and wasted potentiality, Carlyle still considered the French emperor to be 'our last Great Man!' (ibid., p. 286). As such, Napoleon remained for Carlyle worthy of inclusion among the almost superhuman, heroic leaders of history - a view that finds a visual parallel in Gros's depiction of Napoleon as a figure who, though physically diminutive, surpasses all those around him in the fearlessness and magnanimity with which he reaches out to his diseased, despairing troops.

Today, however, few viewers would take Napoleon at the Pest House of Jaffa as an unproblematic representation of 'great man' leadership, or interpret the painting in full accordance with its surface message. One reason for this is that artistic tastes have changed, reducing for many viewers the impact of so obviously propagandistic and sentimental a picture, however brilliant it may be in technique. ${ }^{4}$ In addition, those familiar with the historical record would know of the dark realities behind this luminous image of Napoleonic beneficence, and thus be unable to accept the painting at face value. The painting does, admittedly, have a basis in reality: Napoleon did make an impulsive visit to his plague-ridden troops, touching them freely and even helping to carry the dead - an instance of charismatic behavior that eyewitnesses credited with significantly improving soldiers' morale. But it is also true that, while at Jaffa, Napoleon ordered the massacre of more than two thousand prisoners; the painting by Gros was itself created partly to provide damage control, mitigating Napoleon's reputation for ruthlessness and counteracting rumors that he had actually had his own sick troops poisoned. ${ }^{5}$ In fact, this repugnant incident inspired another, quite different rendering of Napoleon at Jaffa: like so many British caricatures of Napoleon, James Gillray's Poisoning the Sick at Jaffa, a colored engraving from 1799 (rendered again by George Cruikshank in 1814-1815), shows Napoleon as both comical and horrifying, in this case as he surreptitiously orders a doctor to poison the plaguestricken soldiers lying in an adjoining room.

Even without knowing the specifics of the Jaffa situation, many students of leadership today would likely view Gros's tribute to Napoleon as an instance of art in the service of

4. Apropos of this discussion is David Freedberg's (1989, p. 431) point that approaching a work of art solely 'in its own terms' is impossible since 'we cannot ... purify ourselves either of our past or of the insistent present'.

5. On Napoleon's behavior at Jaffa, see Asprey (2000, pp. 302-303) and Dwyer (2007, pp. 416-420). On the painting by Gros and its relation to the historical record, see Crow (2006, pp. 243-244), and Schein (2004). 
'toxic leadership,' as a tool in the cause of Napoleonic self-promotion. ${ }^{6}$ For one thing, the historical record is unavoidable: the Jaffa 'massacre remained one of the few atrocities of the Middle Eastern campaign that had never been successfully hidden or explained away' (Crow 2006, p. 244). For another, the kind of leader deification found in this picture is too blatant to be credible to anyone who approaches leadership critically. Yet the very disconnect between intended meaning and subsequent reinterpretation is a large part of the painting's relevance to leadership studies. The use of beautiful half-truths to distort reality, especially the reality of Napoleon as a leader, points all the more forcefully to the value of examining leadership's representation - and misrepresentation - in art. $^{7}$

A word about the artworks to be discussed here. My selection was guided by the esthetic power or historical interest of these works in and of themselves, and by the abundant variety of leadership-related issues that they address. Moreover, for reasons both of space and the limits of my own knowledge, I focus on works from the western tradition - works that are themselves but a tiny fraction of that tradition's voluminous treatment of leaders, followers, and all the ancillary themes that these terms encompass. ${ }^{8}$

\section{ART'S PORTRAYAL OF LEADERSHIP: DRAWBACKS AND LIMITATIONS}

It is not surprising that literature and cinema have drawn more attention than art from leadership scholars - the strong narrative drive and character development so prevalent in the former media make them seem like more natural avenues for exploring leadership than either painting or sculpture. ${ }^{9}$ In large part, these elements of narration and characterization reflect Gotthold Ephraim Lessing's famous distinction between the intrinsically temporal nature of literary form, as opposed to the spatial forms of painting and sculpture. Ever since its publication in 1766, Lessing's Laocoön: An Essay on the Limits of Painting and Poetry has been the single most influential articulation of the temporal-spatial divide between literature and art. ${ }^{10}$ For Lessing (1766, p. 19), the 'material limitations' of the visual arts mean that there is but a 'single moment

6. The two most thorough examinations of 'toxic' and 'bad' leadership to date are, respectively, Lipman-Blumen (2005) and Kellerman (2004).

7. The manipulation of visual imagery to inform but also to deceive, in a wide range of contexts including political propaganda and advertising, receives incisive analysis throughout Sturken and Cartwright's Practices of Looking (2001).

8. Two recent major museum exhibitions testify to the magnitude of leadership's presentation in non-western art: 'Heroic Africans: Legendary Leaders, Iconic Sculptures' at the Metropolitan Museum of Art, New York, and 'India's Fabled City: The Art of Courtly Luchnow' at the Los Angeles County Museum of Art.

9. For brief reviews of some literary and cinematic approaches to leadership, see the bibliographies in Warner (2011) and Warner and Riggio (2012).

10. The issues surrounding the whole spatial-temporal distinction are complex, and the scholarship on the subject immense. A helpful review of some of the basic positions on the subject appears in the introduction to Wettlaufer (2003, pp. 9-22). In addition to the work by Lee (1967), Steiner (1986), and Wendorf (1983), mentioned above, some of the most stimulating theoretical discussions of literature's relation to the arts, and useful entry points for those wishing to pursue this topic further, appear in Hagstrum (1958); Gombrich (1964); Krieger (1967); Nänny (1986); Mitchell (1987); Frank (1991); and Groys (2011). For parallels and divergences in music's relationship to literature and art, see Albright (1999). 
of time to which art must confine itself.' Although viewing an art work necessarily takes place over some period of time, as we examine it in its parts and then in its entirety, our 'senses perform these various operations with such astonishing rapidity that they seem to us to be but one single operation'; by contrast, the 'consecutive nature of language' makes literature an art not of space but of time (ibid., 85-86, 88).

While Lessing wrote long before the advent of cinema, much of what he says about literature applies to that medium as well. In film, the temporal aspects of literary plot fuse with the visual - it is not for nothing that we speak of 'motion pictures,' given the multiplicity of images and ideas that can be conveyed sequentially or even simultaneously on screen. This yoking of the visual and the temporal only intensifies the film audience's illusion of witnessing actual experience in terms of both time and space. Different as the cinematic and literary media are, both stand apart from the essentially static and spatial nature of art as described by Lessing.

Despite the dominance of Lessing's theory, its critics have rightly objected that, even if a work of art is perceptible in a single instant, the response to that work can include a strongly temporal element, as the eye passes over various details, combining and recombining them in multiple ways. As Wendy Steiner (1986, p. 36) puts it, 'Pictorial perception is ... a matter of temporal processing, like literary perception.' Nevertheless, 'modern theory has not been able to overcome certain spatial-temporal barriers between painting and literature' (ibid., p. 39). Although our response to a work of visual art may involve lengthy contemplation (something Lessing himself admitted), that work itself necessarily remains the record of a moment frozen in time. Lessing's great English contemporary, Sir Joshua Reynolds - himself both painter and theorist - pithily described the temporal constraints on visual art when he declared that the painter 'has but one sentence to utter, one moment to exhibit' (quoted in Wendorf 1983, p. 115).

Despite this limitation, that one moment, rendered in a single image, can suggest multiple perspectives or relationships through the depiction of multiple figures. A case in point is Rodin's group sculpture, The Burghers of Calais (1889), in which the self-sacrificing leading citizens of Calais react to their impending death with markedly different degrees of stoicism, fear, and anguish. Still, however varied or expressive they may be, the figures represented on canvas or in stone are fixed, eternally enacting the moment in which they have been portrayed. Even when an art work deals with multiple characters or differing reactions to a character or event, that work cannot show characters or reactions changing - unlike the fluid alterations rendered within the temporal unfolding of a literary text or film.

Of course, no artist (or author) creates a work in order to demonstrate some component in a theory of leadership. The point is, rather, that the kinds of concerns, ideas, and theories prominent in the study of leadership emerge more easily within the temporal unfolding of verbal art than in the spatial, temporally limited forms of visual art. Consequently, literature would seem to lend itself to the analysis of such concerns far more readily than art. To take but one example: an influential text, The Leadership Challenge by James Kouzes and Barry Posner (2012), identifies five key components of successful leadership: inspiring a vision; challenging conventional processes; enabling others to act; modeling the way; and providing emotional encouragement to subordinates and peers. ${ }^{11}$ In a play, novel, or film, these components of the leaderfollower relationship could emerge repeatedly, in different situations, with numerous

11. Despite numerous revisions to the various editions of their book, Kouzes and Posner (2012) have retained the five points identified above as the core of their evaluation of successful leadership. Their book is, essentially, an extended elaboration on these principles. But any 
variations both between and within characters over time. Not so with a painting or statue, which can only hint at leadership as a process or as a relationship with various stages of development. Because of this, with leadership (as with any other subject) an artwork would have to focus on a single representative moment or incident to carry the weight of its interpretation of that subject.

Besides the temporal challenges identified above, leadership's many intangible qualities elude depiction in visual terms. Some key aspects of leadership are neither palpably demonstrable nor immediately apparent, but emerge only over time, in repeated situations; examples of such intangibles include the leadership components identified by Kouzes and Posner, or such qualities as leaders' abilities to motivate followers, or their failures to inspire followers' trust. What is more, the reactions of followers to leaders often take place internally, beneath the level of physical manifestation. As a result, such phenomena as followers' feelings of confidence in a leader's character or, conversely, disillusionment in a leader's breach of faith, are far more difficult to render in clear visual terms than, say, the more easily recognizable emotional states of grief or joy, not to mention such physical actions as riding a horse or brandishing a sword. Similar problems would beset those seeking to find signs of different leadership styles in art; distinctions between, say, what leadership studies refers to as task-related or relationship-oriented leadership operate at a level of abstraction that resists compelling visual realization. ${ }^{12}$ Given the difficulty of visually rendering the intangible and temporal dimensions of leadership, it is understandable that so many portrayals of leaders are limited to providing a physical likeness or some external indication of the sitter as a titular office holder. It is, after all, much more straightforward to portray a leader as a general, queen, or prime minister than as a strong or weak communicator, a good listener, or a micromanager. Many portraits of official leaders may not even reveal any trace of a leader's official role; how common it is to come across pictures of someone whom we recognize as holding or having held a leadership position - Barack Obama, say, or Winston Churchill - but whom we would be hard pressed to identify as a leader on the basis of appearance alone.

A contemporary example of this phenomenon is Portraits of Power, the series of photographic portraits of world leaders taken by the photographer Platon at the United Nations in $2009 .{ }^{13}$ It is impossible to detect in most of these images any sign of the sitter's specific qualities as a leader, or even to identify a sitter as a leader without prior knowledge of his or her identity. Such depictions as Platon's essentially serve as neutral renderings of a physical likeness, which in turn function as a kind of Rorschach test onto which viewers can project their own interpretations, depending on what external knowledge or attitudes about the leader viewers may have. But even these projections are not necessarily geared specifically toward leadership itself, serving rather as signposts of personality or moral character.

In another kind of portrait, that of the leader as a clearly identified office holder, physical likeness is obviously still present, but the leader's position is indicated by some external sign, such as a uniform or crown. While such images may point to a

of a number of other theories or approaches to leadership would serve equally well here to illustrate the difficulty of expressing in art some of the more abstract concepts in leadership theory.

12. For a pithy review of 'task' and 'relationship' orientations in leadership, see Bass (2008, pp. 42-43).

13. To view an interactive portfolio of Platon's images of heads of state at the United Nations, go to http://www.newyorker.com/online/multimedia/2009/12/07/091207_audioslideshow_platon. 
leader's personal characteristics, their relation to leadership as a set of practices, relationships, or inner qualities is generally much less obvious than their function as visual records of official position or tributes to those in power. For example, the so-called Armada portrait of Queen Elizabeth I, with images of England's triumph over the Spanish Armada shown in the background, explicitly identifies Elizabeth as queen, and implicitly celebrates her wisdom in politics and brilliance in war. ${ }^{14}$ But the painting gives no indication of the degree to which Elizabeth as a leader might or not be Machiavellian, inspiring, charismatic, trustworthy, authoritarian, or adroit at motivating others. True, we may project onto the picture things we already know about Elizabeth's leadership, or we may speculate on what she may have been like as a leader from her grandiose garb and impassive facial expression. Such projections and speculations aside, in terms of actual leadership the portrait tells us next to nothing. This fact has no bearing on the inherent artistic quality or value of the Armada portrait or similar depictions of leaders; it simply reflects the limited role that such depictions play in relation to the study of leadership in terms of practices, skills, attitudes, and interactions between leaders and followers.

It is in this last set of issues that I am interested here, and works of art that engage with these issues. Such works depict leaders as leaders - as persons engaged in the act of leading others - rather than as potentates or mere office holders. Of course, the lines between these types of depiction are not always sharp: the taking of a physical likeness can modulate into character study or even into a reflection of leadership characteristics. Such is the case with George Tames' famous photographic series that captures Lyndon Johnson dispensing 'The Johnson Treatment' to a fellow senator in 1957 (see Figure 1). Nevertheless, the difference between the leader and the office holder is a significant one, as relevant to leadership in art as it is to leadership in practice. The very meaning of leadership in art often parallels the bifurcation of meaning that leadership has in other contexts. In everyday parlance, for instance, 'leadership' often refers to people holding authoritative positions within an organization, as in 'the party leadership.' In this context, the word 'leadership' indicates official status in an organization,
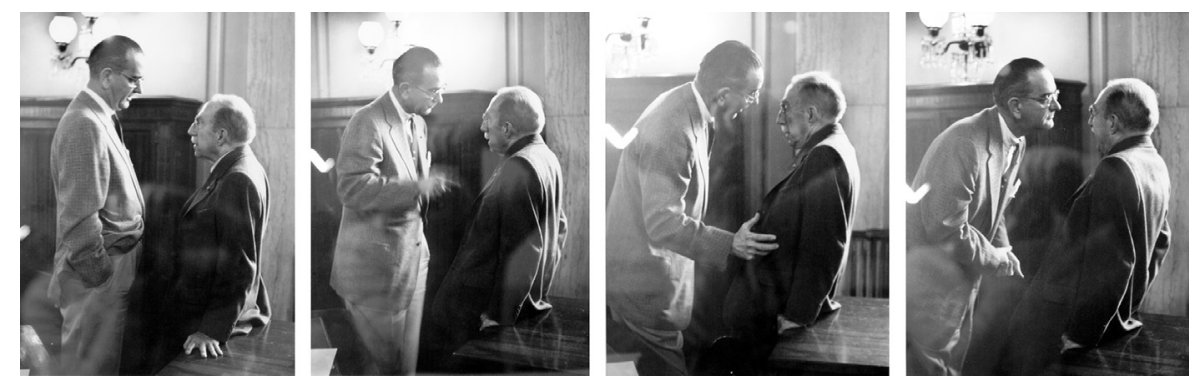

Source: George Tames / The New York Times / Redux.

Figure 1 The Johnson Treatment

14. On the elaborate symbolism of the Armada Portrait, see Hagen and Hagen (2000, pp. 201-205); for an incisive analysis of visual representations of Elizabeth I as a leader, see Frye's (1992) article on myths and realities connected to the famous Tilbury speech, which the Queen delivered just before the battle of the Spanish Armada. 
rather than skill or vision. An analogous sense of leadership informs those portraits of leaders that show only a physical resemblance to the sitter or identify the sitter's rank. In a broader sense, however - the sense usually meant by leadership scholars 'leadership' denotes less the holding of an official position (what Peter Northouse calls 'assigned leadership') than the configurations of skills, attitudes, and behavior found in individuals who often, but not necessarily, hold positions of authority ('emergent leadership,' in Northouse's phrase - see Northouse 2004, pp. 5-6). In contemporary leadership studies, such factors as skill or ineptitude in leadership, variations in leadership style, or the distinctions between transforming and transactional leadership are of greater moment than the specifics of formal position. Indeed, if rank were all, leadership studies as a field would scarcely exist. It is precisely because the capacity to lead whether for good or ill - involves much more than possessing a title that leadership studies is so capacious and multifaceted a discipline. And it is precisely those works of art that go beyond mere identification of title that do justice to that discipline's vast and various nature.

The ensuing discussion will demonstrate some of the ways that, besides the external portrayal of leaders in terms of physical appearance or title, visual art abounds with probing presentations of leadership. The portraits of the powerful, even if they amount to no more than a likeness, may be fascinating in their own right, but they do not necessarily offer much to the student of leadership. In contrast, through the vividness and affective power of the visual image, art can reveal profound insights or pose troubling questions about such things as the character, ethics, and comportment of individual leaders; the nature of the relationship between leaders and followers; the different roles that leaders can play; and the different forms that leadership in general can take. Far from having merely peripheral or decorative interest, art provides a powerful tool with which to study leadership in all of its human complexity.

\section{ART'S PORTRAYAL OF LEADERSHIP: ADVANTAGES AND POSSIBILITIES}

We have already seen how some of art's limitations apply to the treatment of leadership, no less than to any other subject matter. Yet for every limitation on the artistic medium, there are advantages that circumvent that limitation and use the inherent nature of art to achieve effects different from, but no less powerful than, those of literature and cinema. These advantages include the ability to link internal states to external appearance and action; the capacity of art to present persons and events in a state of simultaneous action; and the representativeness that an art work can have, giving it the power to distill ideas, relationships, and individual character traits into a single, concrete visual image.

Art's power to make physically manifest emotional and mental states provides one measure of what Leonardo da Vinci saw as painting's superiority to poetry. As Rensselaer Lee observes, for Leonardo painting could not only represent natural reality more vividly than poetry, but could also 'represent the motions of the mind by which he [Leonardo] chiefly means the passions of the soul in so far as they are expressed by movements of the body' (Lee 1967, p. 60). While conceding that poets can express certain intricacies of the mind that painters cannot, Leonardo still affirmed the artistic depiction of mental activity as an even greater achievement than the delineation of the external world. A much later literary figure's tribute to painting makes a similar point: in the preface to his novel, Joseph Andrews, Henry Fielding (2008, pp. 5-6) asserts that 'It hath been 
thought a vast Commendation of a Painter, to say his Figures seem to breathe; but surely, it is a much greater and nobler Applause, that they appear to think.' Long before Fielding - or, for that matter, Leonardo - Plutarch also pointed out art's capacity to delineate not merely physical reality but inner character. It is, indeed, pleasing that Plutarch provides a point of intersection between leadership studies and art history as two scholars in these different fields - Barbara Kellerman and Richard Wendorf, respectively - cite Plutarch's famous analogy between the biographer and the painter. In the introduction to his life of Alexander the Great, Plutarch compares biography and portraiture in their ability to reveal character through small but significant details, rather than through 'glorious exploits' (quoted in Kellerman 2010, p. 32). Like the painter who shows character through facial expression, so the biographer 'must be permitted to devote [himself] to the signs of the soul in men ...' (quoted in Wendorf 1983, p. 101). Indeed, in terms that anticipate Leonardo and other commentators on art as a revealer of inner identity, Plutarch in another section of his Lives declares, 'a portrait which reveals character and disposition is far more beautiful than one which merely copies form and feature' (quoted in Wendorf 1983, p. 102).

As the above comments suggest, although a work of art cannot show a character evolving over time, it produces its most potent effects by conveying the essence of a person's inner identity. This issue is obviously relevant to leadership, in which both moral character and individual personality play such various, complex, and important roles.

Despite art's greater challenges, relative to literature, in rendering events in temporal sequence, one great advantage of visual art is actually a concomitant of its atemporal structure. Unlike the literary work which can only unfold gradually through the process of reading, the spatial arrangement of figures on a single canvas is able to render multiple events and persons through an image that is instantaneously, or almost instantaneously, comprehensible. This is why group portraits or paintings can have such suggestive power about human interactions and can convey in a single scene a wide range of individual human responses to the same event.

Embodying this quality is Leonardo's Last Supper, which records the varied, simultaneous responses of the disciples to the announcement that one of them will betray Christ. To take a very different example, Hogarth's crowded scenes from London life allow us to observe, often with delight in the artist's clever juxtapositions of events and characters, his ironic commentary on the paradoxes, inconsistencies, and injustices of society. A notable example is Gin Lane, in which a gin-sodden mother ignores her falling child's danger, while impoverished Londoners try to pawn what few goods they have, and chaos and violence permeate a leaderless London in the background, with the King's statue symbolically overshadowed by the pawnbroker's shop emblem.

The preceding paragraphs have addressed two fundamental aspects of art's relation to the depiction of leadership: the external manifestation of internal states of mind or feeling, and the simultaneous depiction of different persons and actions in a single image. Equally relevant here is art's capacity for representativeness, which amply compensates for any temporal limitations on the spatial forms of painting and sculpture. If it is true that the artist has, as Reynolds put it, 'but one moment to exhibit,' that moment can be replete with broader significance about the event, person, or persons depicted. Because artists cannot show multiple moments in succession in a single image, they must select a key or representative moment in a life, story, or historical event. Yet this necessity, while in one sense a limitation, is in another sense a manifestation of the potential of art to endow a single moment with extraordinary expressive power.

These points can be clarified with reference to artistic depictions of David and Goliath from the first Book of Samuel. Any illustration of the Biblical account would have to 
restrict itself to a single incident out of the narrative as a whole. But through that very selectivity great artists have presented radically distinct views of David and, by extension, different suggestions about the nature of heroism, courage, faith, and struggle. For instance, in what is arguably the world's most famous sculpture, Michelangelo's David (1504), the magnificent young challenger stands alone, slingshot in hand, taking the measure of the unseen Goliath whom he is about to kill. A different moment and different interpretation of David appear in Donatello's only slightly less famous statue (c. 1430-1440) depicting David as a slender, almost foppish youth standing in strangely pensive triumph over the giant's enormous severed head. Michelangelo gives us David in preparation for his great deed, with no Goliath in sight; Donatello gives us David after the combat is over. The Baroque sculptor, Bernini, shows David (1624) neither before nor after the event but in medias res, as it were - athletic body contorted, eyebrows furrowed, lips compressed as he twists around in the very act of hurling the stone (see Figure 2). In Rubens's painting of David and Goliath (c. 1616), we find the giant just barely alive; the slingshot has hit its mark and now David is about to bring his fearsome sword down on the neck of the prostrate giant, implacably carrying out God's judgment on the Philistine giant.

One of the most unusual depictions of David, Andrea Castagno's parade shield emblazoned with a wiry, windblown David (c. 1450), goes beyond the previously discussed works in overcoming the temporal limitations of visual imagery; though in so doing, the artist departs from conventional representation. Like Bernini, Castagno

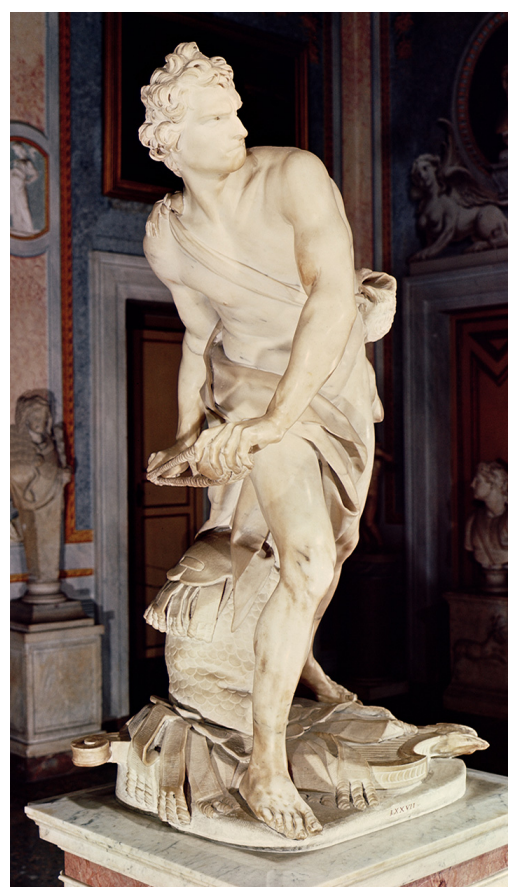

Source: Galleria Borghese, Rome, Italy / Giraudon / The Bridgeman Art Library.

Figure 2 David, 1623-1624 (marble), Bernini, Gian Lorenzo (1598-1680) 
shows David with the slingshot already in motion, the stone about to be released. But unlike Bernini (or any of the other artists mentioned above), 'Castagno has presented the action and its outcome simultaneously: David holds the loaded sling, but already the head of the slain Goliath lies at his feet' (http://www.nga.gov/collection/gallery/ gg4/gg4-1145.html). Given the design's presence on a ceremonial shield, its clever manipulations of temporal sequence actually send a message that has less to do with the interpretation of David than with an implicit warning to enemies: if you fight us, as Goliath fought the righteous David, you will meet Goliath's fate. (See Figure 3, in the color plate section facing this page.)

For all their variations, each of these artworks, instead of being constrained or weakened by the need to center on a single moment, exploits this feature of the visual arts to create a scene rich with implications for the attentive viewer to ponder. Each in some way also conveys an awareness of time: the anticipation of the climactic event in Michelangelo; Goliath's severed head as a sign of what has just transpired in Donatello; the frozen moment in Bernini that makes us think of the future results of David's contorted body in action; Rubens's trace of the past in the bloodied forehead of Goliath and sign of the impending future in the sword above Goliath's neck; and the exuberant defiance of spatial limitation found in Castagno's simultaneous depiction of cause and result in one remarkably compressed image.

David's encounter with Goliath marked the beginning of his gradual ascent to leadership as King of Israel. Because of this, an artwork rendering this scene implicitly evokes the eventual emergence of David's role as a leader. But in his actual struggle with the giant, David marshaled no followers and gave no commands, overcoming the enemy solely through ingenuity, skill, and courage. Thus my discussion of David and Goliath has less to do with leadership per se than with art as a spatial form which, despite restrictions on its treatment of temporal events, possesses its own powers of distillation and compression that verbal media cannot match. These powers are much in evidence in an art work more directly related to leadership, where the artist's selection of a representative moment, while possibly motivated by considerations of composition and esthetic effect, seems also to have been politically astute.

This work is Jacques-Louis David's Coronation of Napoleon (1805-1807). David originally considered showing the most striking moment at that coronation specifically, Napoleon's theatrical upstaging of the Pope by taking the crown and placing it on his own head. Though agreed upon earlier by the parties involved (Knapton 1963, p. 244), Napoleon's self-crowning came across as an act of breathtakingly audacious self-assertion, one that would be hard for any artist to resist. Nevertheless, after reviewing various possibilities, David chose to show Napoleon after having crowned himself, and just as he is about to crown Josephine (see Figure 4, in the color plate section facing this page). The final composition may well reflect David's prudent desire to avoid any suggestion of Napoleonic hubris; Walter Friedlander (1952, p. 29) suggests that it 'did not seem wise to Napoleon, or perhaps to his counselors, to show this historic scene in a public picture; it would have proclaimed urbi et orbi the ruler's usurpation.' At the same time, David's choice of the moment between two coronations - Napoleon is already crowned, Josephine has not quite yet received the crown from her emperor-husband - suggests the multiplicity of events taking place at this ceremony. The picture reminds us of the necessarily prior act of self-crowning without actually placing it before our eyes; in this way, the artist simultaneously evokes a past event even as he depicts the present and points toward the future (the imminent crowning of Josephine). This aspect of the picture was noted already by David's 


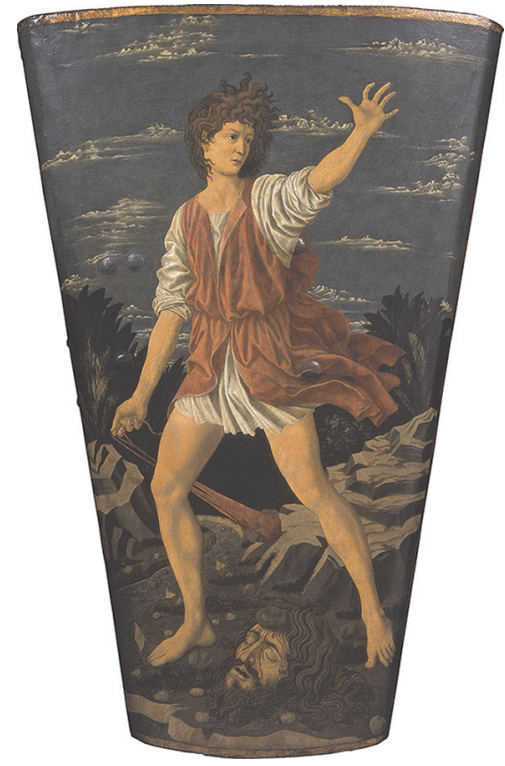

Source: National Gallery of Art, Washington, DC, USA / The Bridgeman Art Library.

Figure 3 David with the Head of Goliath, c. 1450-1455 (tempera on leather on wood), Castagno, Andrea del (1423-1457)

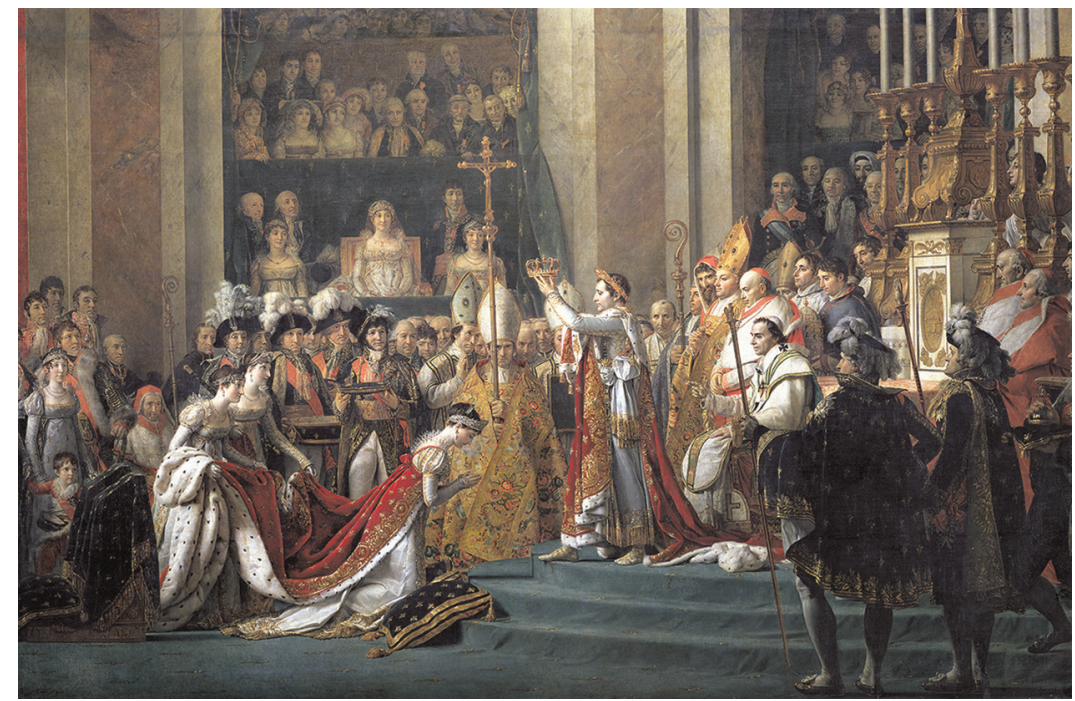

Source: Louvre, Paris, France / The Bridgeman Art Library.

Figure 4 The Consecration of the Emperor Napoleon (1769-1821) and the Coronation of the Empress Josephine (1763-1814), 2nd December 1804, detail, 1806-1807 (oil on canvas), David, Jacques Louis (1748-1825) 


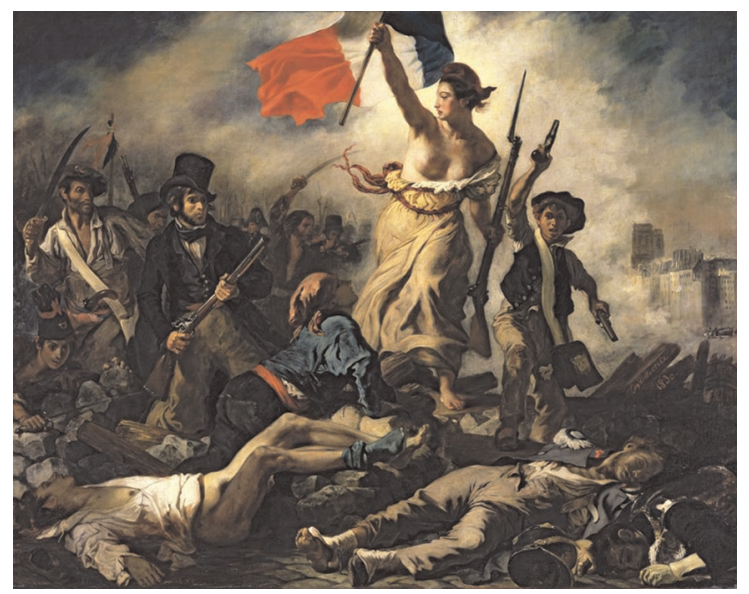

Source: Louvre, Paris, France / The Bridgeman Art Library.

Figure 7 Liberty Leading the People, 28th July 1830 (oil on canvas), Delacroix, Ferdinand Victor Eugene (1798-1863)

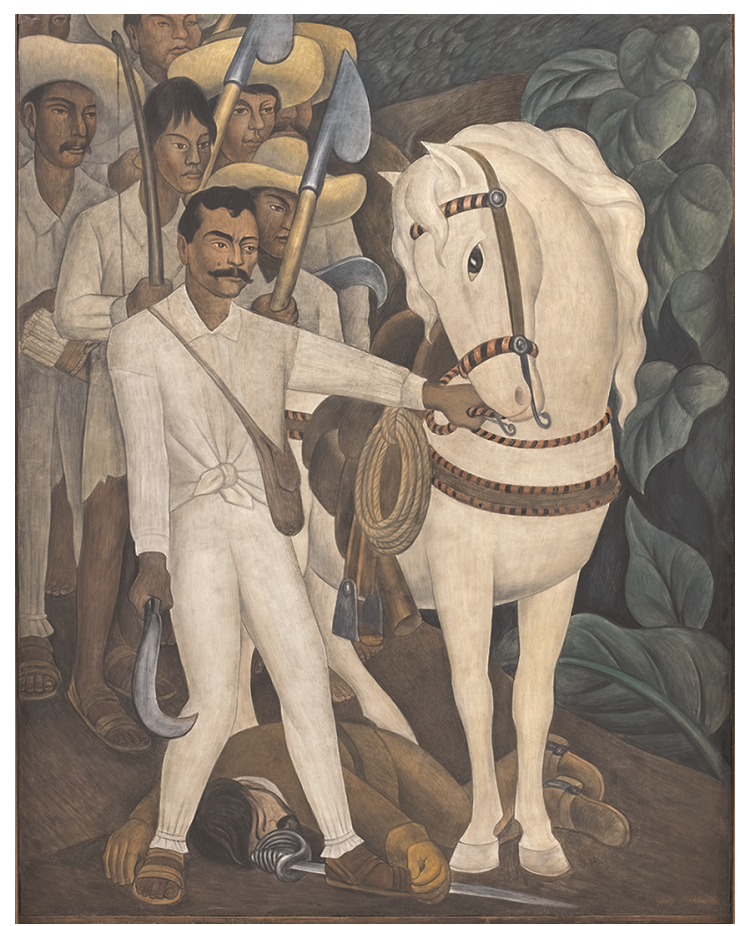

Source: Abby Aldrich Rockefeller Fund / The Museum of Modern Art, New York, NY, USA.

Figure 8 Rivera, Diego (1886-1957) (c) ARS, NY. Agrarian Leader Zapata. 1931. Fresco, 7'93/4" × 6'2" $(238.1 \times 188 \mathrm{~cm})$ 
contemporaries and has long been part of the critical-interpretive discourse about the painting (Porterfield and Siegfried 2006, p. 129).

Whatever motivations of prudence or politics may have influenced it, David's choice of this particular moment clearly provided the Coronation with remarkable temporal complexity and depth; the painting is a fascinating example of the power of the representative moment in art. In addition, by selecting the crowning of Josephine, David was able to convey a more nuanced, multilayered message about the nature of Napoleonic power than would probably have been possible in a depiction of Napoleon crowning himself. The focus on Josephine's coronation shows Napoleon extending and consolidating the power implicit in his own prior gesture of self-crowning. Rather than turning inward, Napoleon's power in the painting is centrifugal, a force that, while emanating from himself, reaches out to embrace others. Thus David's final version affirms Napoleon not only as the acquirer and possessor of power, but as its very source; the picture emphasizes not power seized and used for self-glorification, but power that radiates outward, shared as its ultimate wielder sees fit. Moreover, Napoleon's authority in the painting is all the more firmly established because it is a given - Napoleon's imperial status may only be seconds old and self-conferred but still, the painting presents that status as a fait accompli.

The painting's vast composition allows David to include details and persons whose simultaneous depictions convey the outsized scope of Napoleon's ambitions and grandeur. The kneeling Josephine, all demureness, piety, and submissive followership (an image quite at odds with the actual private lives of Napoleon and Josephine); the Pope sitting passively in the background, with eyes averted and shoulders slumped; the throngs of awed spectators; and Napoleon himself enacting a fusion of civil and religious authority in crowning his own wife - all of these elements converge into a monumental vision of Napoleon's astonishing self-confidence, defiance, and irresistible will to power. These qualities, however, emerge with more subtlety and less danger of negative interpretation than might have been the case had David rendered the event's climactic moment: Napoleon's self-coronation. A work of extraordinary sophistication and tact in its depiction of Napoleon as a leader, the Coronation is also a piece of unmitigated propaganda, in which painterly skill, ingenious composition, and a blend of accurate reportage and fabrication serve to further the emperor's self-promoting agenda - albeit with a softer touch than the artist had originally planned.

Like the images of David and Goliath, The Coronation of Napoleon - whatever one may think of the ideology behind it - shows how the eternally fixed quality of the single moment in art, far from being a weakness, can lend itself to artistic inventiveness and both intellectual and emotional complexity. With leadership, as with any other subject, viewers may imaginatively enter the single moment that the artist has frozen forever. In works with the clusters of significant imagery and detail discussed here, engaged viewers become 'readers' of the artwork, contemplating its layers of signification, interpreting and re-interpreting the scene before them which, though immutable, can nonetheless grow in meaning, suggestiveness, and affect.

\section{CASE STUDIES: FEDERICO OF URBINO, NAPOLEON, ZAPATA}

The foregoing analysis has set forth aspects of the interplay of art and leadership, with particular attention to matters of theory and the inherent nature of the artistic medium as a vehicle for representing leadership. The passages below round out this discussion by turning to three paintings that lend themselves to the kind of close visual analysis just 
discussed. In each of these works, simultaneity of action, the choice of a representative moment, and the expression of inner qualities through external signs contribute in varying degrees and modes to the creation of thought-provoking, aesthetically powerful depictions of leaders. In each case, moreover, the depiction of a leader grows beyond the portrait of an individual to stimulate viewers' own reflections on leadership and on the power of images to shape perceptions, ideas, and emotional responses.

The earliest of these paintings (c. 1475) is Pedro Berruguete's Federico da Montefeltro and His Son (see Figure 5). In equal parts condottiere and connoisseur, Federico used the spoils of mercenary warfare to establish one of the most celebrated ducal courts of Renaissance Europe. His portrait may seem an unlikely image of a leader - that of a man simply sitting and reading. To many modern viewers, the image will appear even more anomalous as the reader is garbed in heavy armor, with a large sword at his side; as Theodore Rabb (2011, p. 77) points out, Federico is 'dressed in a manner that is virtually unique in the annals of portraiture'. But the picture's significance lies not in an attempt to replicate Renaissance reading habits; even a warrior-prince would be unlikely to visit his library clad in armor. Rather, the painting uses various symbolic

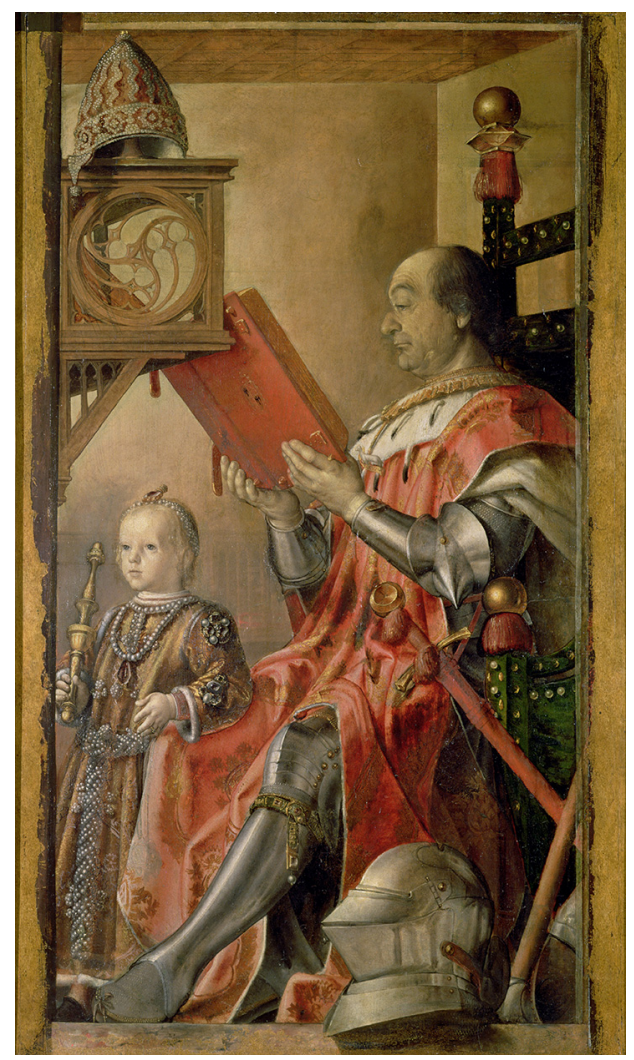

Source: Galleria Nazionale delle Marche, Urbino, Italy / The Bridgeman Art Library.

Figure 5 Portrait of Federigo da Montefeltro, Duke of Urbino (1422-1482) and his son Guidobaldo (d. 1508) (oil on panel), Berruguete, Pedro (c. 1450-1504) 
details to convey in one compact, highly expressive image the blend of martial, intellectual, spiritual, and familial qualities for which Federico was known. ${ }^{15}$

Berruguete's painting conveys a crucial and widely acknowledged component of Federico's style of leadership - the integration of intellectual pursuits with military prowess. Though a man of learning, engrossed here in reading a beautifully bound book - and one that marks his piety as well, since it is St Gregory the Great's commentary on the Book of Job - the Duke is both prepared for battle and highly skilled at it. The preparedness is indicated by his armor and sword, the skill by tokens of the international acclaim that Federico's achievements as a condottiere earned him: the elegant mitre at the top of the painting was a gift from the Sultan of Persia, the ermine on Federico's shoulders a gift from the King of Naples, and most impressive of all, the Order of the Garter on his left leg an honor bestowed by King Edward IV of England. Moreover, the disparate aspects of Federico's character presented in the painting are not only coexistent, but interdependent. As noted by Federico's librarian, Vespasiano da Bisticci, 'It is difficult for a leader to excel in arms unless he be, like the Duke [Montefeltro], a man of letters, seeing that the past is a mirror of the present. A military leader who knows Latin has a great advantage over one who does not' (quoted in Kirkbride 2008, p. 108). To Federico, knowledge of culture and philosophy not only supplemented military success, but was essential to it.

The multiple dimensions of Federico's character and leadership receive further emphasis from the painting's inclusion of his son and heir, Guidobaldo. In fact, despite the Duke's warlike appearance, there is a sweetness to the scene, as little Guido rests his arm casually on his father's knee. Without interacting directly, the two side-by-side figures, despite their cumbersome dress, appear relaxed and at ease with one another. Even more important, the image suggests that the father models for his son 'the dialectic of the vita activa-vita contemplative' espoused by Federico's close friend, the architect and philosopher Leon Battista Alberti (Kirkbride 2008, p. 108). There's even a hint here of the son being trained for his future responsibilities, with his incipient emergence as a leader suggested by the scepter in his hand. And indeed, Guidobaldo, though plagued by ill health, succeeded his father as condottiere, Duke, and patron of the arts, in which latter capacity he received poetic tribute from William Butler Yeats (Clark 1968, p. 112).

Family man, warrior, intellectual, spiritual contemplative, ruler - in life, all of Federico's disparate roles seemed to fuse into a single harmonious identity. Berruguete's densely allusive portrait captures and connects these roles, showing them not to be at odds with one another, but to be facets of one unified personality and outlook. By testifying to Federico's own remarkable capacity to encompass and reconcile so many diverse aspects of human experience, the painting distills his character and characteristics as a leader, even though it shows no overt act of leadership. Thus the picture is a fitting representation of the man who, when asked which single quality was most important for a leader, famously replied, 'essere umano' - 'to be human' (quoted in Osborne 2003, p. 73). ${ }^{16}$

15. For information on Federico's life and Berruguete's painting, I have drawn on Kirkbride (2008), Osborne (2003), and two websites: one for the Palazzo Ducale at Urbino (http://www. palazzoducaleurbino.it/) (Urbino 2007-2012), and the other for a 2007 exhibit devoted to Federico at the Morgan Library in New York: 'Federico da Montefeltro and His Library' (http://www.themorgan.org/about/press/FedericoRelease.pdf) (Federico 2007).

16. From a leadership studies perspective, the painting also suggests the fusion of traits and skill as essential components of Federico's leadership. Certainly the preoccupation for much of the twentieth century with leaders' 'traits' has diminished, giving way more to other approaches, especially those emphasizing situational and contingent leadership. But while leadership traits are not sufficient to explain leadership, many scholars have affirmed their 
Berruguete's representation of Federico relies on understatement and implication; only through subtle visual signals does the painting even identify its subject as being a leader at all. In marked contrast is David's flamboyant masterpiece of Napoleonic portraiture, Bonaparte Crossing the Alps (1801), a picture that instantaneously and unambiguously presents its subject as a leader (see Figure 6). Depicting Napoleon

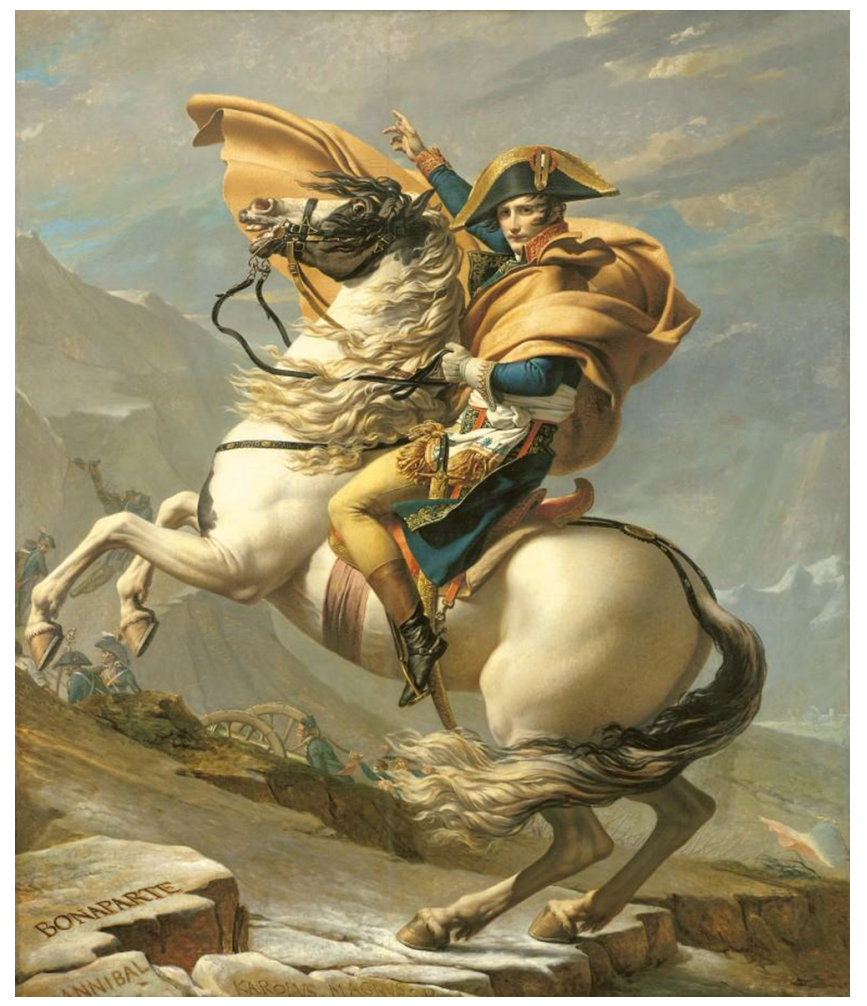

Source: Musée Nationale du Chateau de Malmaison, Rueil-Malmaison, France / Giraudon / The Bridgeman Art Library.

Figure 6 Napoleon (1769-1821) Crossing the Alps at the St Bernard Pass, 20th May 1800, c. 1800-1801 (oil on canvas), David, Jacques Louis (1748-1825)

\footnotetext{
ongoing importance; see, for example, the useful overview of traits theories in Northouse (2004, especially pp. 15-24), and in Kirkpatrick and Locke (1995). Of course, there is no way that the Berruguete portrait could portray all aspects of leadership; it does not, for instance, depict charismatic behavior, transformational or transactional leadership, or the idea of Federico as a Carlylean 'great man' or superhuman hero; it does, however, admiringly portray Federico in terms of certain traits and skills relevant to his style of leadership. The traits suggested include intellectual curiosity; a belief in learning; piety (since the text he reads is a religious commentary); and familial responsibility (as indicated by the proximity of his young son, learning from his father's example). The importance of skills comes through the visual suggestion of Federico's combination of military readiness and prowess, as indicated by his armor, weaponry, and the formal recognition of proven martial skill by the Order of the Garter.
} 
in the age-old tradition of equestrian leaders, David followed Napoleon's explicit instructions that he be presented sitting calmly astride a 'fiery' horse, rather than the more prosaic mule that actually carried Napoleon across the Alps. ${ }^{17}$ The rearing steed with windswept mane, the rider with his cloak billowing forward, the upward thrust of Napoleon's arm toward the mountaintops and sky: all these elements combine to create a paradigmatic image of the 'Great Man' as leader. Set against the backdrop of a stormy sky and shadowy soldiers struggling with cannon, the whole painting is a visual equivalent of fortissimo.

The backstory of this painting's creation at the behest of King Charles IV of Spain, its popularity, multiple versions, and relations to the historical record have been ably and thoroughly studied before (see Hautecoeur 1954, pp. 197-199; and Lee 2004). Here, instead, I address several of the picture's compositional features that relate significantly to leadership: Napoleon's right hand pointing forward; the relation of horse to rider; and Napoleon's simultaneously twisting posture and outward gaze.

As in so many works by David, the open or gesturing hand plays an important role in Bonaparte Crossing the Alps. Yet this relatively small part of the painting irresistibly draws our eyes, at least as much as does the massive, dominant figure of the rearing animal, the dramatic natural setting of the Alps, and the image of the legendary leader himself. In fact, that crucially placed hand has a semiotic power disproportionate to its size. As in Gros's later picture of Napoleon at Jaffa, Napoleon here has one gloved and one ungloved hand (as it turns out, opposite hands in the two paintings). That the pointing hand is bare gives a personal, intimate quality to the gesture, as an ungloved handshake does. In contrast to his gloved left hand, which holds the horse's reins, Napoleon's pointing right hand, being bare, implies that it is Napoleon the man, less than the commander, who is showing us the way. The outstretched index finger of that hand, pointing upward and forward, is the highest point of the rider-horse cluster that fills most of the painting; that fingertip is the closest thing to the mysterious but implicitly noble, lofty goal toward which Napoleon directs his viewers.

Napoleon's gesture, though simple, entails considerable interpretive ambiguity and potential multiplicity of suggestion. In literal terms, of course, Napoleon is simply pointing ahead, toward Italy, his army's destination on the other side of the Alps. But the upward loft of the hand implies something more ineffable. Certainly the time-honored, positive metaphorical connotations of height are present here: Napoleon leads us not only forward but up. It is as if the crossing of the Alps entailed the scaling not just of physical mountains, but of something higher and nobler, which those mountains represent. Indeed, the positive connotations of height in general are here intensified by the association of spiritual meaning with such lofty things as the mountains that Napoleon is about to cross and, above all (both literally and figuratively), the heavens toward which he seems to be reaching. The other, more relaxed fingers on Napoleon's hand also make it seem as if he is not only pointing but trying to grasp something found only in the realm of the invisible. Rather than some rigidly directive sign - for example, a clenched hand with firmly flexed finger pointing

17. For thorough discussions of the painting's creation and reception, see Lee (2004) and Rabb (2011, pp. 152-158). A famously stark contrast to David's glorified version of Napoleon's crossing is Paul Delaroche's doggedly realistic painting, Bonaparte Crossing the Alps (1848), in which a rather forlorn and chilly-looking Napoleon sits huddled on a mule - his actual mode of transport across the Alps. 
straight ahead - Napoleon's relaxed pointing gesture and the graceful sweep of his outstretched arm come across not as an imperious command, but as an invitation, a gracious offer to join him in the pursuit of some sublime goal.

At the same time that his bare right hand indicates the path ahead, extends an invitation, and seems to grasp at some transcendent entity, Napoleon's left, gloved hand firmly grasps the horse's reins; together with his left leg pressing into the horse's flank, this detail conveys Napoleon's unquestionable control. That control becomes even more emphatic through the steed's clearly delineated physical power, as it rears up in agitation on its hind legs, with a 'crazed expression' which, as Philippe Bordes (2005, p. 87) shrewdly observes, is framed 'against the billowing cloth, a detail that leads back to the calm confidence of the rider.' The horse's seething energy only accentuates the power of the rider who can control that energy and who, in a sense, becomes associated with that violence by his proximity to it - it is, after all, his horse that rears in frenzy. The horse's manic quality only heightens the presentation of Napoleon as a leader who is powerful enough not just to curb but also to direct - and potentially to unleash - so wild a force.

Yet this expression of force comes not from the steed alone, but from Napoleon's body. While moving forward, Napoleon also turns sideways, thus projecting vitality and dynamism. That twisting gesture implies the very act of leading, since in turning to his side, Napoleon seems to establish a connection with his unseen followers, as if urging them on in the direction that he is already moving. Numerous images of leaders rely on a strikingly similar pose to indicate dynamism and to identify the leader as someone who, while moving forward, turns sideways or back to pull his or her followers along. In Verrocchio's famous statue of Bartolomeo Colleoni (1496), a similar twisting motion occurs, suggesting the rider's energetic appeal to his unseen soldiers, implicitly just off to the side and slightly behind him. Napoleon himself appears elsewhere in this twisting pose, as in Gros's portrait of the young leader at the Bridge of Arcole (1797) where Napoleon, with a sword in one hand and a banner in the other, moves forward even as he turns his head back in an implied gesture of appeal and inspiration to his troops. Similarly, and possibly in imitation of Gros, the 1821 engraving of Joan of Arc by Philippe-Alexandre Le Brun de Charmettes shows Joan, like Napoleon, wielding both sword and banner, and rushing forward while turning her head back to urge her followers onward. One of the most famous of all such images, Delacroix's Liberty Leading the People (1830), has the female personification of liberty stride forward even as she turns her head in a gesture of seeming encouragement to the motley citoyens crowded around her (see Figure 7, in the color plate section facing page 15). Clearly, then, David's Bonaparte Crossing the Alps both draws on and extends a long-standing tradition whereby the visual work of art, limited in its capacity to represent the dynamics of leader-follower relations, can use a simple positioning of the body to convey leadership as a process of pulling followers along, guiding them forward and modeling the forward thrust that they themselves must make.

Related to the twist of the body in this particular picture is Napoleon's gaze - directed at us, the viewers of the painting. As Napoleon points ahead and gazes out, seemingly beyond the confines of the painting, it is we who are placed in the role of potential followers, beckoned by Napoleon to join in his mountain-scaling, heaven-touching enterprise. The combination of the pointing bare hand and the face turned toward us a face that, in David's rendering, is grave without being threatening, calm yet intense in its apparent direct engagement with the viewer - emphasizes the personal appeal of the leader to the follower-viewer: the hand shows us the direction and the goal (nebulous 
though that goal is). That it is a bare hand emphasizes Napoleon's humanity, and thus his bond with us, the implicit followers to whom he shows the way. The face turns as if to ask: will you follow me? The implied bond between the spectators, gazing at Napoleon, and Napoleon himself gazing out of the canvas, recalls the symbiosis between leader and follower in a charismatic relationship. As Ronald Riggio (2004, p. 158) observes, with reference to Max Weber's notions of charismatic leadership, 'it is in the relationship between the leader's qualities and the followers' devotion to the leader and belief in the leader's cause that charisma lies.' David's visual evocation of the bond between the seen leader and his unseen followers, effected through the linked details of bare pointing hand and outward-directed gaze (Napoleon looking at us as much as we look at him), vividly testifies to the painter's combined powers of imagination, composition, and execution. At the same time, this evocation would also satisfy Napoleon's own sense of the usefulness of visual images to his purposes of fostering the loyalty, support, and devotion of his followers.

From a more skeptical standpoint, of course, the artist's deployment of the ambiguous hand gesture with the painting's suggestions of a higher, but never explicitly identified purpose, serve the interests of imperial warmongering all too well. Bonaparte Crossing the Alps can be read as yet another in the long line of manipulative masterpieces in which true motives - conquest, power, wealth, ego gratification - become veiled by a gauzy tissue of supposedly 'higher' goals. At first, David's picture may look like the veritable embodiment of transforming leadership. The rearing horse, the brave general pitting himself against the stormy elements, the all-too-human sign of the bare hand that points forward and up - all of this suggests an idealistic leader who ennobles and elevates his followers, and who enables his fellow human beings to rise above their mundane selves to fulfill the potential of their better natures. But to anyone who recalls the blood-stained path of Napoleon's ascent to glory, the picture must come across as something quite different: as an unwitting visual rendition of what Bernard Bass has termed 'pseudo-transformational' leadership, where hazy sentimentality allows a leader to exploit his followers' desire for self-validation and a noble purpose to serve far from altruistic ends. ${ }^{18}$

Both Berruguete's portrait of Federico, and David's of Napoleon, convey not merely pictures of an individual, but visions of leadership and of a leader's proper role. A very different ideology of leadership emerges in Diego Rivera's Agrarian Leader Zapata of 1931 (see Figure 8, in the color plate section facing page 15). This painting is one of hundreds, if not thousands, of visual images commemorating the Mexican political activist, associate of Pancho Villa, and revolutionary military leader, Emiliano Zapata. Though a warrior like Federico and Napoleon, Zapata in Rivera's painting appears in civilian garb, part of a homogeneous group of weathered but resolute peasants or campesinos. Rather than commanding them from on high, Zapata appears as an egalitarian leader, a peasant among peasants, as indicated by the white clothing which he, like the others in the picture, wears. In apparel, size, and position he is very much one with the people he leads; in fact, his position as

18. 'Transformational leadership' has, of course, been one of the most dominant themes in leadership studies since the concept was described in James MacGregor Burns' 1978 Pulitzer Prize-winning book, Leadership (where Burns originally used the term 'transforming,' rather than 'transformational'). Analyses of, and variations on, the theme of transformational leadership continue to proliferate in scholarly studies. A useful qualification to the theory is Bernard Bass's (2008, p. 233) notion of 'pseudo-transformational leadership,' in which a seemingly visionary, inspirational mode of leadership can actually prove illusory or even destructive. 
leader makes him seem part of a unit, a wedge-like movement of the common people at whose forefront he happens to be.

That Zapata is a leader, however, is clear: he is in front, his expression has a severity and determination greater than shown on the faces of the other men, he grasps the reins of the beautiful, large white horse that, in seeming sympathy with him and his cause, inclines its head towards him. And as he moves forward, Zapata steps, symbolically, on and over the old order that he and his followers must destroy, namely the order of the oppressive landowners known as hacendados. Zapata's left foot stands on the sword of a dead enemy, presumably a hacendado whom the campesinos have slain, dressed unlike them in a brown suit. While visually suggesting triumph over the violence represented by the sword on which Zapata stands, the image acknowledges the violence within the campesino movement itself, not only through the body of the landowner but the farm implements that the workers carry, a variety of hoes and scythes, like the one in Zapata's hand. In fact, resembling a sword at the same time that it is clearly a scythe, Zapata's tool-as-weapon metonymically evokes the hammer and sickle of communist symbolism, while also reflecting Rivera's well-known communist sympathies.

Two more features deserve attention here: the relation of the horse to Zapata, and the motif of white clothing. The strikingly beautiful horse, with its well-appointed gear, probably belonged to the dead hacendado. We now see it claimed, like the land and other goods that the revolutionaries appropriated, as Zapata stretches out a firm hand to grasp its bridle. His action, emphasized by the ramrod straightness of his arm controlling the horse, as well as his position in the front of the group, mark him as a leader. But the horse itself seems appreciative, almost tender in its response to Zapata, as suggested by its gentle expression and remarkably graceful turn of the head in a broad, sweeping arc toward the rebel leader; Zapata's act becomes, paradoxically, one of simultaneous control and liberation. In addition, the horse's dazzling whiteness links it to the whitegarbed Zapata and other men, thereby suggesting an affinity between the animal part of the natural world - and the righteous, albeit violent, rebel-workers.

It is also appropriate that Zapata would be the one to take charge of the horse, given his well-known expertise as a horseman. Indeed, statues of Zapata throughout Mexico depict him in the tradition of equestrian leader portrayals, with Zapata shown on horses in various degrees of action, from a calm walk to a canter to agitated rearing. In Rivera's painting, however, it is significant and fitting that Zapata is not shown mounted: though in control of the animal, he remains on the same level as the other rebels, rather than on horseback above them. Yet by including the horse, Rivera manages simultaneously to pay tribute to Zapata's own horsemanship, and to signify the union of nature itself - in the form of the horse - with the peasant class that Zapata supported, fought for, and led.

The clothing motif marks an intriguing departure from the actual appearance of the historical Zapata, who favored the charro costume associated with horsemanship: decorated pants and short jacket, silver spurs, broad sombrero. Rivera of course knew how Zapata usually dressed, and in fact portrayed him elsewhere in the typical charro outfit. Nor was Rivera alone in this knowledge of Zapata's sartorial preferences. In 1931, when the artist completed this work for exhibition at the Museum of Modern Art in New York, Zapata had been dead for 12 years, and photographs taken during his life had already achieved iconic status. Consequently, most Mexican and many American art viewers would know that the Zapata they saw in Rivera's image was not how Zapata actually looked; these viewers would doubtless understand that image not as literal depiction but as symbolic homage to Zapata's spirit of solidarity 
with the campesinos. These viewers might even recognize in the picture an affirmation of the leadership mode that Rivera himself espoused - one based on communal action and socialism rather than on hierarchy and class privilege. Rivera's own interest in leadership as material for art is apparent in his comment on the Mexican mural movement in which he himself played so prominent a role: 'For the first time in the history of monumental painting, Mexican muralism ended the focus on gods, kings, and heads of state' and 'made the masses the hero of monumental art.' 19

\section{CONCLUSION}

One of the most rewarding aspects of the three works just discussed is the way that each of them reveals small details coalescing into a coherent vision of a leader. Both individually and as a group, these works exemplify art's potential as an arena for the study of leadership, and testify to the reciprocal illumination between art and leadership studies mentioned at the outset of this article. That illumination, however, can reveal more than the specific views of leadership found in works of art, or the artistic techniques that make such views interesting or compelling. Seen in broader perspective, a study of art's relation to leadership brings out the carefully crafted, even choreographed aspects of leadership's representation. An artwork may reflect followers' perceptions of a given leader, and may also shape those perceptions, as well as those of the followers themselves and their relationship to the leader. Apropos here is Michael Hogg's social identity theory of leadership, according to which followers engage in the social construction of leadership, since it is followers' perceptions of themselves, and their behavior as followers, that can 'empower individuals as leaders, imbue them with charisma ... and set up conditions that are conducive to the exercise and possible abuse of power' (Hogg 2001, p. 196-197). In some instances, as with Gros's rendering of Napoleon at Jaffa, or of David's equestrian tribute to Napoleon crossing the Alps, art assists in this construction by investing the leader not simply with charisma but with superior, even superhuman attributes. Yet art can also move in the opposite direction, eliding actual differences between leader and led, and emphasizing - or fabricating - a leader's oneness with the follower group in terms of appearance, behavior, and other 'prototypical' features of that group (ibid., p. 191). An example is Rivera's depiction of Zapata not as flamboyant charro but as humble campesino. (Of course, as we have seen, Rivera's purpose in this picture was neither prevarication nor literal rendering, but an openly symbolic homage to Zapata's dedication to the peasants of Mexico.)

In his book, The Mask of Command, the distinguished war historian John Keegan (1988, p. 11) writes that 'Heroic leadership - any leadership - is ... a matter of externals as much as internalities. The exceptional are both shown to and hidden from the mass of humankind, revealed by artifice, presented by theatre.' Artifice and theatricality are not necessarily bad things, as Keegan's study of military leaders in different times and places shows. Rather, these qualities are tools that can be used, like most tools, for good or evil. But whatever ends they serve, our understanding of these tools, and of their relation to leadership, can richly benefit from the study of art, in which artifice and theatricality play crucial roles, just as they do in leadership. Even

19. The comment is quoted on the informative website devoted to this image at the Museum of Modern Art, New York: http://www.moma.org/collection/object.php?object_id=80682 (MOMA 2011). 
more important, such study can lead us to a fuller understanding of two profoundly interconnected forces that go far beyond leadership to touch nearly every aspect of human experience: the art of power and the power of art.

\section{REFERENCES}

Albright, Daniel (1999). Untwisting the Serpent: Modernism in Music, Literature, and Other Arts. Chicago: University of Chicago Press. Print.

Asprey, Robert B. (2000). The Rise of Napoleon Bonaparte. New York: Basic Books. Print.

Bass, Bernard, with Ruth Bass (2008). The Bass Handbook of Leadership: Theory, Research and Managerial Applications. New York: Free Press. Print.

Bordes, Philippe (2005). Jacques-Louis David: Empire to Exile. New Haven and London: Yale University Press. Print.

Boylston, Scott (2008). 'Establishing Regimes of Truth: A Study of the Relationship between Leaders, Power, and Artistic Expression.' In Joanne Ciulla (ed.), Leadership at the Crossroads, Vol. 3: Leadership and the Humanities. Westport, CT: Praeger, pp. 213-235. Print.

Bryson, Norman (1983). Vision and Painting: The Logic of the Gaze. New Haven, CT: Yale University Press. Print.

Burns, James MacGregor (1978). Leadership. New York: Harper and Row. Print.

Carlyle, Thomas (1840). On Heroes, Hero-Worship and the Heroic in History. London: Chapman and Hall. Print.

Ciulla, Joanne B. (ed.) (2008). Leadership and the Humanities. Vol. 3 of Joanne Ciulla (ed.), Leadership at the Crossroads. Westport, CT and London: Praeger.

Clark, Kenneth (1968). Civilisation: A Personal View. New York: Random House. Print.

Conger, Jay A. and Rabindra N. Kanungo (1989). Charismatic Leadership: The Elusive Factor in Organizational Effectiveness. San Francisco: Jossey-Bass. Print.

Crow, Thomas (1985). Painters and Public Life in Eighteenth-Century Paris. New Haven, CT: Yale University Press. Print.

Crow, Thomas (2006). Emulation: David, Drouais, and Girodet in the Art of Revolutionary France. Revised edn. New Haven, CT: Yale University Press. Print.

Delestre, Jean-Baptiste (1867). Gros: Sa Vie et ses Ouvrages. Paris: J. Renouard. Print.

Dwyer, Philip (2007). Napoleon: The Path to Power. New Haven, CT and London: Yale University Press. Print.

Elkins, James (1996). The Object Stares Back: On the Nature of Seeing. New York: Simon and Schuster. Print.

Emerson, Ralph Waldo (1903). The Complete Works of Ralph Waldo Emerson. Edward Waldo Emerson (ed.). Vol. 10. Cambridge, MA: Houghton-Mifflin. Print.

'Federico da Montefeltro and His Library' (2007). The Morgan Library and Museum. Web. November 20, 2012.

Fielding, Henry (2008). Joseph Andrews and Shamela. Thomas Keymer (ed.). New York: Oxford University Press. Print.

Frank, Joseph (1991). The Idea of Spatial Form. New Brunswick, NJ: Rutgers University Press. Print.

Freedberg, David (1989). The Power of Images: Studies in the History and Theory of Response. Chicago: University of Chicago Press. Print.

Friedlander, Walter (1952). David to Delacroix. Translated by Robert Goldwater. Cambridge, MA: Harvard University Press. Print.

Frye, Susan (1992). 'The Myth of Elizabeth at Tilbury.' The Sixteenth Century Journal, 23, 95-114. Print.

Gombrich, E.H. (1960). Art and Illusion: A Study in the Psychology of Pictorial Representation. London: Phaidon. Print.

Gombrich, E.H. (1964). 'Moment and Movement in Art.' Journal of the Warburg and Courtauld Institutes, 27, 293-306. Print. 
Groys, Boris (2011). 'The Border between Word and Image.' Theory, Culture, and Society, 28, 94-108. Print.

Hagen, Rose-Marie and Rainer Hagen (2000). What Great Paintings Say: Old Masters in Detail. Koln: Taschen. Print.

Hagstrum, Jean (1958). The Sister Arts: The Tradition of Literary Pictorialism and English Poetry from Dryden to Gray. Chicago: University of Chicago Press. Print.

Hautecoeur, Louis (1954). Louis David. Paris: La Table Ronde. Print.

'Heroic Africans: Legendary Leaders, Iconic Sculptures' (2011). Metropolitan Museum of Art. Web. November 1, 2012.

Hogg, Michael A. (2001). 'A Social Identity Theory of Leadership.' Personality and Social Psychology Review, 5 (3), 184-200. Print.

'India's Fabled City: The Art of Courtly Luchnow' (2010). Los Angeles County Museum of Art. Web. November 1, 2012.

Johnson, Charles (2008). 'Art History and Leadership Studies.' In Joanne Ciulla (ed.). Leadership at the Crossroads. Vol. 3 of Leadership and the Humanities. Westport, CT: Praeger, pp. 189-212. Print.

Keegan, John (1988). The Mask of Command. New York: Penguin. Print.

Kellerman, Barbara (2004). Bad Leadership: What it is, How it Happens, Why it Matters. Cambridge, MA: Harvard Business Review Press. Print.

Kellerman, Barbara (ed.) (2010). Leadership: Essential Selections on Power, Authority, and Influence. Boston: McGraw-Hill. Print.

Kirkbride, Robert (2008). Architecture and Memory: The Renaissance Studioli of Federico da Montefeltro. New York: Columbia University Press. Print.

Kirkpatrick, Shelley A. and Edwin A. Locke (1995). 'Leadership: Do Traits Matter?' In J. Thomas Wren (ed.). The Leader's Companion: Leadership Insights Through the Ages. New York: Free Press, pp. 133-143. Print.

Knapton, Ernest John (1963). Empress Josephine. Cambridge, MA: Harvard University Press. Print.

Kouzes, James M. and Barry Z. Posner (2012). The Leadership Challenge: How to Make Extraordinary Things Happen in Organizations. San Francisco: Jossey-Bass.

Krieger, Murray (1967). 'The Ekphrastic Principle and the Still Movement of Poetry; or, Laokoön Revisited.' Murray Krieger, The Play and Place of Criticism. Baltimore: Johns Hopkins University Press, pp. 105-128. Print.

Küpers, Wendelin M. (2004). 'Arts.' In George R. Goethals, Georgia J. Sorenson, and James MacGregor Burns (eds). Encyclopedia of Leadership. Vol. 1. Thousand Oaks, London, New Delhi: Sage Publications, pp. 47-54. Print.

Lee, Rensselaer W. (1967). Ut Pictura Poesis: The Humanistic Theory of Painting. New York: Norton. Print.

Lee, Simon (2004). 'Napoleon Crossing the Alps at the Great Saint Bernard Pass.' In Christopher John Murray (ed.). Encyclopedia of the Romantic Era, 1760-1850. Vol. 2. London: Taylor and Francis, pp. 785-786. Print.

Lessing, Gotthold Ephraim (1962). Laocoön: An Essay on the Limits of Painting and Poetry. Translated by Edward Allen McCormick. Indianapolis and New York: Bobbs-Merrill.

Lipman-Blumen, Jean (2005). The Allure of Toxic Leaders. Oxford: Oxford University Press. Print.

Mitchell, W.J.T. (1987). Iconology: Image, Text, Ideology. Chicago: University of Chicago Press. Print.

Mitru, Anu M. (2011). 'Learning to Look: The Art of Observation and Leadership Development.' In Michael Harvey and Ronald E. Riggio (ed.). Leadership Studies: The Dialogue of Disciplines. Cheltenham, UK: Edward Elgar, pp. 184-196. Print.

MOMA: The Collection: Diego Rivera (2011). Agrarian Leader Zapata. The Museum of Modern Art. Web. November 30, 2012.

Nänny, Max (ed.) (1986). Iconicity in Literature. A special edition of Word \& Image: A Journal of Verbal/Visual Enquiry, 2 (3). Print.

National Gallery of Art, USA: The Collection: Andrea del Castagno (2012). David with the Head of Goliath. Web. December 2, 2012. 
Northouse, Peter G. (2004). Leadership: Theory and Practice. Thousand Oaks, London, New Delhi: Sage Publications. Print.

Osborne, June (2003). Urbino: The Story of a Renaissance City. Chicago: University of Chicago Press. Print.

Porterfield, Todd and Susan L. Siegfried (2006). Staging Empire: Napoleon, Ingres, and David. University Park, PA: Pennsylvania State University Press. Print.

Rabb, Theodore K. (2011). The Artist and the Warrior: Military History through the Eyes of the Masters. New Haven, CT and London: Yale University Press. Print.

Riggio, Ronald E. (2004). 'Charisma.' In George R. Goethals, Georgia J. Sorenson, and James MacGregor Burns (eds). Encyclopedia of Leadership. Vol. 1. Thousand Oaks, London, New Delhi: Sage Publications, pp. 158-162. Print.

Schein, Alexandra (2004). 'Napoleon in the Pest House at Jaffa, 1804.' In Christopher John Murray (ed.). Encyclopedia of the Romantic Era, 1760-1850. Vol. 2. London: Taylor and Francis, pp. 786-787. Print.

Steiner, Wendy (1986). The Colors of Rhetoric: Problems in the Relation Between Modern Literature and Painting. Chicago: University of Chicago Press. Print.

Strauss, Monica (1984). 'Cultural Leadership and the Avant-Garde.' In Barbara Kellerman (ed.). Leadership: Multidisciplinary Perspectives. Englewood Cliffs: Prentice-Hall, pp. 179-197. Print.

Sturken, Marita and Lisa Cartwright (2001). Practices of Looking: An Introduction to Visual Culture. New York: Oxford University Press. Print.

Urbino: Visite Guidate alla città e al Palazzo Ducale: Galleria Nazionale delle Marche (20072012). Web. November 1, 2012.

Warner, Nicholas O. (2011). 'Leadership in Literary Perspective.' In Michael Harvey and Ronald E. Riggio (eds), Leadership Studies: The Dialogue of Disciplines. Cheltenham, UK: Edward Elgar, pp. 171-183. Print.

Warner, Nicholas O. and Ronald E. Riggio (2012). 'Italian-American Leadership in Hollywood Films: Images and Realities.' Leadership, 8 (3), 211-227. Print.

Wendorf, Richard (1983). 'Ut Pictura Biographia: Biography and Portrait Painting as Sister Arts.' In Richard Wendorf (ed.). Articulate Images: The Sister Arts from Hogarth to Tennyson. Minneapolis: University of Minnesota Press, pp. 98-124. Print.

Wettlaufer, Alexandra (2003). In the Mind's Eye: The Visual Impulse in Diderot, Baudelaire and Ruskin. Amsterdam, New York: Editions Rodopi. Print.

Wren, J. Thomas (2009). 'Reinventing the Liberal Arts through Leadership.' In J. Thomas Wren, Ronald E. Riggio, and Michael A. Genovese (eds). Leadership and the Liberal Arts: Achieving the Promise of a Liberal Education. New York: Palgrave Macmillan, pp. 13-36. Print. 